\title{
Pengembangan nilai Islami peserta didik melalui integrasi Alquran dan Hadis dalam pembelajaran biologi
}

Mualimin Mualimin

Program Pascasarjana, Universitas Negeri Yogyakarta, Indonesia

Email: mualimin.sehati@gmail.com

\begin{abstract}
Abstrak
Pendidikan nasional bertujuan untuk membentuk manusia yang beriman dan bertakwa serta berakhlak mulia, tidak hanya mengembangkan potensi kecerdasan kognitif. Salah satu upaya yang dapat dilakukan untuk mewujudkan tujuan tersebut adalah dengan mengembangkan nilai Islami peserta didik melalui integrasi Alquran dan Hadis dalam pembelajaran biologi. Integrasi Alquran dan Hadis dalam pembelajaran biologi dapat mengarahkan terbentuknya pengetahuan tentang konsep biologi dan juga dapat mengembangkan nilainilai Islami peserta didik. Metode penelitian ini adalah studi pustaka (library research) yang dilakukan dengan mengumpulkan berbagai sumber informasi yang relevan seperti artikel jurnal ilmiah, buku, dan sumber lainnya tentang integrasi Alquran dan Hadis dalam pembelajaran biologi untuk mengembangkan nilai Islami peserta didik. Hasil menunjukkan bahwa integrasi Alquran dan Hadis dalam pembelajaran biologi dapat dilakukan dengan: 1) Mendata dan menganalisis ayat Alquran dan Hadis yang sesuai dengan pokok bahasan atau materi biologi baik secara tersirat maupun tersurat, 2) Mengimplementasikan pengintegrasian ayat Alquran dan Hadis yang sudah ditemukan dalam proses pembelajaran biologi dengan pemilihan model pembelajaran tertentu yang
\end{abstract}


sesuai; 3) Melakukan evaluasi terhadap proses integrasi yang sudah dilakukan dalam proses pembelajaran biologi. Integrasi Alquran dan Hadist dalam pembelajaran biologi perlu dilakukan untuk menumbuhkan nilai-nilai Islami pada diri peserta didik guna tercapainya tujuan pendidikan nasional.

Kata kunci: Nilai Islami, Integrasi Alquran dan Hadis, Pembelajaran Biologi

\begin{abstract}
National education aims to shape people of faith and piety and noble character, not only to develop the potential of cognitive intelligence. One effort that can be done to realize these goals is to develop Islamic values of students through the integration of the Quran and Hadith in learning biology. The integration of the Quran and Hadith in biology learning can lead to the formation of knowledge about biological concepts and can also develop Islamic values of students. This research method is library research which is carried out by collecting various relevant sources of information such as scientific journal articles, books, and other sources about the integration of the Quran and Hadith in biology learning to develop Islamic values of students. The results show that integration of the Quran and Hadith in learning biology can be done by: 1) Recording and analyzing verses of the Quran and Hadith that are in accordance with the subject or biological material both implicitly or explicitly, 2) Implementing the integration of verses of the Quran and Hadith found in the process of learning biology by selecting certain appropriate learning models; 3) Evaluating the integration process that has been done in the biology learning process. The integration of Quran and Hadith in learning biology needs to be done to foster Islamic values in students to achieve national education goals.
\end{abstract}

Keywords: Islamic Values, Integration of the Quran and Hadith, Biology Learning

\title{
Pendahuluan
}

Pendidikan memiliki peran yang sangat vital dalam pembangunan sumber daya manusia yang berkualitas. Sumber daya manusia yang berkualitas salah satunya dapat dilihat dari baiknya moral dan akhlak. Untuk membangun moral dan akhlak yang baik dapat dilakukan melalui proses pendidikan di sekolah, walaupun harus didukung juga oleh pendidikan di lingkungan keluarga dan masyarakat. Pengembangan moral dan akhlak yang baik di sekolah dapat 
dilakukan dengan penanaman nilai-nilai iman dan taqwa (religius) melalui proses pembelajaran (Suryaningsih, 2018).

Undang-Undang Nomor 20 Tahun 2003 tentang Sistem Pendidikan Nasional Pasal 3 menyebutkan bahwa tujuan pendidikan nasional adalah mengembangkan potensi peserta didik agar menjadi manusia yang beriman dan bertakwa kepada Tuhan Yang Maha Esa, berakhlak mulia, sehat, berilmu, cakap, kreatif, mandiri, dan menjadi warga negara yang demokratis serta bertanggung jawab. Amanah konstitusi tersebut membuktikan bahwa tujuan pendidikan di Indonesia tidak hanya mengembangkan potensi kecerdasan kognitif saja tetapi juga membentuk manusia yang berkarakter agamis. Namun kenyataannya, jika kita lihat di sekolah-sekolah yang ada sekarang ini lebih banyak menekankan penanaman konsep, rumus, dan teori-teori; mata pelajaran dan jam pelajaran di sekolah lebih didominasi oleh bidang ilmu umum yang sentuhan agamanya sangat minim sekali.

Sesuai dengan tujuan pendidikan nasional di atas, dimensi spiritual keagamaan yakni menjadi manusia yang beriman dan bertakwa serta berakhlak mulia merupakan poin capaian yang diharapkan dapat berkembang pada diri peserta didik melalui proses pendidikan. Pemerintah sebenarnya telah berupaya untuk mewujudkan tujuan pendidikan tersebut dalam kurikulum 2013 yakni dengan menjadikan dimensi spiritual sebagai kompetensi inti (KI) dalam pembelajaran. Semua mata pelajaran yang diajarkan di sekolah harus mengarah pada tercapainya sikap spiritual sebagai hasil dari proses belajar untuk menjadikan peserta didik menjadi insan yang beriman dan bertaqwa serta berakhlak mulia.

Pemerintah memang telah menjadikan dimensi spiritual sebagai kompetensi inti dalam pembelajaran, akan tetapi dalam Permendikbud Nomor 22 Tahun 2016 tentang Standar Proses belum menjelaskan secara teknis tentang proses pembelajaran yang dapat mengarahkan peserta didik untuk mencapai kompetensi sikap spiritual, sehingga pengembangannya dapat dilakukan masingmasing oleh guru melalui proses pembelajaran pada mata pelajaran. Pada sekolah Islam yang dalam hal ini menggunakan dasar-dasar ajaran agama Islam, salah satu cara yang dapat dilakukan oleh guru untuk membangun kompetensi sikap spiritual adalah dengan mengembangkan nilai-nilai Islami pada proses pembelajaran pada mata pelajaran. Biologi sebagai salah satu mata pelajaran yang diajarkan di sekolah pada kurikulum 2013 juga punya andil besar untuk mewujudkan pengembangan nilai Islami di sekolah, terutama pada sekolah berbasis Islam. Cara yang dapat dilakukan untuk mewujudkan pengembangan 
nilai Islami peserta didik pada mata pelajaran biologi diantaranya adalah dengan mengintegrasikan Alquran dan Hadis sebagai sumber pengembangan nilai Islami pada pembelajaran biologi.

Bedasarkan paparan di atas, perlu kiranya ditelusuri bagaimana pengembangan nilai Islami peserta didik melalui integrasi Alquran dan Hadis dalam pembelajaran biologi. Tulisan ini akan membahas tentang posisi Alquran dan Hadis dalam pembelajaran biologi, Peran Alquran dan Hadis dalam pengembangan nilai Islami, serta cara-cara pengembangan nilai Islami peserta didik melalui integrasi Alquran dan Hadis pada pembelajaran biologi yang dapat dilakukan oleh guru-guru di sekolah Islam untuk mewujudkan tujuan pendidikan nasional yakni mengembangkan peserta didik yang beriman dan bertakwa serta berakhlak mulia.

\section{Metode}

Tulisan ini menggunakan metode studi pustaka (library research). Studi pustaka dilakukan dengan mengumpulkan data dan informasi dari berbagai sumber seperti artikel jurnal ilmiah, buku, hasil seminar, dan sumber relevan lainnya. Data dan informasi yang dikumpulkan berupa posisi dan peran Alquran dan Hadis dalam pembelajaran (biologi), serta cara pengintegrasian Alquran dan Hadis dalam pembelajaran biologi untuk mengembangkan nilai Islami peserta didik. Sumber referensi yang diperoleh ditelaah dan dianalisis penulis, kemudian hasilnya dicatat dan dikualifikasikan menurut kerangka yang sudah di tentukan.

\section{Hasil dan Pembahasan}

\section{Posisi Alquran dan Hadis dalam Pembelajaran Biologi}

Ditinjau dari bahasa, Alquran berasal dari Bahasa Arab dari kata kerja qara'a - yaqra'u - qur'anan yang berarti bacaan atau sesuatu yang dibaca berulang-ulang (Iryani, 2017). Menurut istilah, Alquran adalah kalam Allah yang bersifat mukjizat yang diturunkan kepada Nabi Muhammad saw. melalui perantara Jibril dengan lafal dan maknanya dari Allah Swt. yang dinukilkan secara mutawatir, membacanya merupakan ibadah, dimulai dengan Surat AlFatihah dan diakhiri dengan Surat An-Nas. Alquran adalah kalamullah yang diturunkan kepada Nabi Muhammad melalui Malaikat Jibril sebagai mukjizat dan berfungsi sebagai hidayah (petunjuk) (Kemenag, 2010: 7). 
Alquran adalah bacaan yang paling sempurna. Alquran disebut juga AlFurqan yang berarti kitab pembeda antara yang sah dan haram, antara yang baik dan yang buruk, antara perintah yang diwajibkan dan larangan untuk ditinggalkan. Alquran juga disebut Ad-Dzikr atau kitab peringatan bagi umat manusia untuk selalu mengingat Tuhannya, mengingat semua perintah-Nya dan semua larangan-Nya. Alquran disebut juga Al-Huda, diturunkan kepada umat manusia sebagai kitab arahan dalam melakukan tugasnya sebagai khalifatullah fil ardhi, sebagai khalifah Allah di bumi. Alquran disebut juga Al-Mau'idhah, sebagai kitab nasihat. Alquran disebut juga As-Syifa', karena dapat berfungsi sebagai penyembuh atau obat-obatan atau sebagai penawar penyakit berbahaya. Alquran disebut juga Al-Hikmah, atau kitab kebijaksanaan yang berisi ayat-ayat tentang kebijaksanaan yang sangat dibutuhkan oleh umat manusia. Alquran disebut juga Al-Khair, atau kitab kebaikan yang memberi petunjuk kepada umat manusia tentang kebaikan yang datang dari Allah Swt.

Hadis didefinisikan sebagai segala perkataan $\mathrm{Nabi}$, perbuatan, dan hal ihwal Nabi Muhammad saw. Ulama Hadis menerangkan bahwa yang termasuk "hal ihwal", ialah segala pemberitaan tentang Nabi Muhammad saw., seperti yang berkaitan dengan himmah, karakteristik, sejarah kelahiran, dan kebiasaan-kebiasaanya (Shalih, 2009: 21). Dalam Kamus Besar Bahasa Indonesia, Hadis didefinisikan sebagai sabda, perbuatan, takrir (ketetapan) Nabi Muhammad saw. yang diriwayatkan atau diceritakan oleh sahabat untuk menjelaskan dan menentukan hukum Islam (Badan Pengembangan dan Pembinaan Bahasa Kemendikbud, 2016). Hadis atau sunnah adalah perkataan, perbuatan dan pengakuan atau ketetapan yang disandarkan kepada Rasullah saw. (Abdurrahman, 2011: 192).

Pembelajaran adalah proses interaksi peserta didik dengan pendidik dan sumber belajar pada suatu lingkungan belajar. Pembelajaran merupakan usaha sengaja, terarah dan bertujuan agar orang lain dapat memperoleh pengalaman yang bermakna (BSNP, 2006: 30). Biologi sebagai ilmu memiliki kekhasan tersendiri dibandingkan dengan ilmu-ilmu yang lain. Biologi merupakan salah satu ilmu pengetahuan yang mempelajari makhluk hidup dan kehidupannya dari berbagai aspek persoalan dan tingkat organisasinya. Biologi merupakan bagian dari sains, sehingga apa yang berlaku pada bidang sains juga berlaku pada bidang biologi. Biologi merupakan cabang ilmu yang berkaitan dengan ilmu alam yang mengkaji tentang organisme kehidupan beserta lingkungan sekitar.

Alquran sebagai kitab suci agama Islam, selain mengkaji persoalan tentang 
agama juga mengkaji tentang ilmu pengetahuan, termasuk ilmu pengetahuan biologi. Banyak ayat Alquran yang menjelaskan fenomena biologi yang dapat dijadikan rujukan untuk pengakajian dalam materi atau pokok bahasan pembelajaran biologi. Selain Alquran, Hadis juga merupakan sumber agama Islam yang juga banyak membahas tentang ilmu biologi. Alquran dan Hadis dapat dikaji dan dikaitkan dengan pokok bahasan dalam proses pembelajaran biologi untuk diambil nilai Islaminya agar peserta didik dapat semakin beriman dan bertakwa kepada Tuhan Yang Maha Esa, serta berakhlak mulia sesuai yang diharapkan dari tujuan pendidikan nasional.

Biologi merupakan wahana untuk meningkatkan pengetahuan, keterampilan, sikap, dan nilai serta bertanggungjawab kepada lingkungan, masyarakat, bangsa, negara, yang beriman dan bertakwa kepada Tuhan Yang Maha Esa. Biologi juga berkaitan dengan cara mencari tahu dan memahami tentang diri sendiri, alam semesta dan kehidupan secara sistematis. Jadi pada hakikatnya kajian materi agama dan biologi memiliki hubungan yang sangat erat dan jika diintegrasikan akan menghasilkan pembelajaran yang bermakna (Nurasni, Darmawati, \& Yustini, 2015). Biologi mempelajari tentang fakta, prosedur, dan fenomena yang berkaitan dengan makhluk hidup dan kehidupannya yang merupakan penciptaan Tuhan. Dengan mempelajari biologi diharapkan peserta didik semakin mengagungkan kebesaran Tuhan.

Pembelajaran biologi mengungkapkan fakta-fakta ilmiah, dapat dilakukan dengan berbagai metode. Salah satu metode yang dapat digunakan adalah dengan kegiatan penyelidikan atau penelitian ilmiah. Alquran dan Hadis telah memberikan sistem yang lengkap dan sempurna yang mencakup semua aspek kehidupan manusia, termasuk kegiatan-kegiatan ilmiah atau penyelidikanpenyelidikan ilmiah. Kegiatan ilmiah merupakan bagian yang integral dari keseluruhan sistem Islam di mana masing-masing bagian memberikan sumbangan terhadap yang lainnya. Alquran sebagai kalam Allah, diturunkan bukan untuk tujuan-tujuan yang bersifat praktis. Dalam kapasitasnya sebagai hudal linnas, Alquran memberikan informasi stimulan mengenai fenomena alam dalam porsi yang cukup banyak, yakni sekitar tujuh ratus lima puluh ayat (Suryaningsih, 2018). Ayat-ayat dalam Alquran ini dapat dikaji melalui pembelajaran biologi dalam rangka menemukan fakta-fakta ilmiah.

Wahyu pertama yang diterima Nabi Muhammad saw. yakni Surat Al'Alaq 1-5 mengandung indikasi pentingnya proses investigasi (penyelidikan). Kata iqra', menurut dari akar kata yang berarti menghimpun. Dari menghimpun lahir makna lainnya seperti menyampaikan, menelaah, mendalami, meneliti, 
mengetahui ciri sesuatu, dan membaca baik yang tertulis maupun tidak. Sedangkan dari segi obyeknya, perintah iqra' itu mencakup segala sesuatu yang dapat dijangkau oleh manusia, seperti fenomena alam yang dipelajari dalam biologi (Shihab, 2008). Informasi Alquran tentang fenomena alam ini dimaksudkan untuk menarik perhatian manusia kepada Pencipta alam semesta yakni Allah Swt. dengan mempertanyakan dan merenungkan wujudwujud alam serta mendorong manusia agar berjuang mendekat kepada-Nya. Fenomena alam adalah tanda-tanda kekuasaan Allah. Pemahaman terhadap alam itu akan membawa manusia lebih dekat kepada Allah SWT. Pandangan Alquran tentang sains biologi dan teknologi dapat ditelusuri dari pandangan Alquran tentang ilmu. Alquran telah meletakkan posisi ilmu pada tingkatan yang hampir sama dengan iman seperti tercermin dalam Surat Al-Mujadalah ayat 11: "... niscaya Allah akan meninggikan orang-orang yang beriman di antara kamu dan orang-orang yang diberi ilmu pengetahuan beberapa derajat". Alquran sangat menekankan pentingnya membaca (mengamati) gejala alam dan merenungkannya. Alquran mengambil contoh ilmu biologi sebagai tanda kekuasaan Allah untuk dipikirkan oleh manusia.

\section{Peran Al Qur'an dan Hadis dalam Pengembangan Nilai Islami}

Istilah nilai adalah sesuatu yang abstrak yang tidak bisa dilihat, diraba, maupun dirasakan dan tidak terbatas oleh ruang lingkupnya. Nilai sangat erat dengan pengertian-pengertian dan aktivitas manusia yang kompleks, sehingga sulit ditentukan batasnya. Karena keabstrakannya itu maka timbul bermacammacam pengertian, di antaranya sebagai berikut.

Pertama, nilai adalah sesuatu yang memberi makna dalam hidup, yang memberi acuan, titik tolak dan tujuan hidup. Nilai adalah sesuatu yang dijunjung tinggi, yang dapat mewarnai dan menjiwai tindakan seseorang. Nilai lebih dari sekedar keyakinan, nilai selalu menyangkut pola pikir dan tindakan, sehingga ada hubungan yang amat erat antara nilai dan etika (Steeman dalam Adisusilo, 2013:56).

Kedua, nilai adalah suatu pola normatif, yang menentukan tingkah laku yang diinginkan bagi suatu sistem yang ada kaitannya dengan lingkungan sekitar tanpa membedakan fungsi-fungsi bagian-bagiannya (Arifin, 2010: 141).

Ketiga, nilai adalah standar-standar perbuatan dan sikap yang menentukan siapa kita, bagaimana kita hidup dan bagaimana kita memperlakukan orang lain. Tentu saja nilai-nilai yang baik bisa menjadikan orang lebih baik, hidup 
lebih baik dan memperlakukan orang lain secara lebih baik (Linda dan Richard Eyre dalam Adisusilo, 2013:57).

Beberapa pengertian tentang nilai di atas dapat dipahami bahwa nilai merupakan suatu yang abstrak, ideal, dan menyangkut persoalan keyakinan terhadap yang dikehendaki, dan memberikan corak pada pola pemikiran, perasaan, dan perilaku. Dengan demikian, untuk melacak sebuah nilai harus melalui pemaknaan terhadap keyakinan lain berupa tindakan, tingkah laku, dan pola pikir.

Nilai-nilai Islami pada hakekatnya adalah kumpulan dari prinsip-prinsip hidup, ajaran-ajaran tentang bagaimana manusia seharusnya menjalankan kehidupannya di dunia ini, yang satu prinsip dengan prinsip lainnya saling terkait membentuk satu kesatuan yang utuh tidak dapat dipisahkan. Jadi pada dasarnya Islam merupakan satu sistem, satu paket, paket nilai yang saling terkait satu sama lain, membentuk yang disebut sebagai teori-teori Islam baku.

Dalam kamus besar Bahasa Indonesia, nilai-nilai agama Islam atau nilainilai keislaman adalah bagian dari nilai material yang terwujud dalam kenyataan pengalaman rohani dan jasmani (Badan Pengembangan dan Pembinaan Bahasa Kemendikbud, 2016). Nilai-nilai agama Islam merupakan tingkatan integritas kepribadian yang mencapai tingkat budi (insan kamil). Nilai-nilai Islami bersifat mutlak kebenarannya, universal, dan suci. Kebenaran dan kebaikan agama mengatasi rasio, perasaan, keinginan, nafsu-nafsu manusiawi, dan mampu melampaui subjektivitas golongan, ras, bangsa, dan stratifikasi sosial.

Ogunbado \& Al-Otaibi (2013: 6), menyatakan bahwa nilai Islami merupakan prinsip dan standar yang berlandaskan pada Alquran, Sunnah Nabi, dan literatur Islam yang relevan dalam pencapaian kualitas keagamaan. Nilai Islami adalah suatu prinsip yang diyakini kebenarannya berlandaskan pada Alquran, Sunnah dan Ijtihad berupa nilai aqidah dan akhlak yang dijadikan pedoman dalam kehidupan (Susilowati, 2017: 80-81).

Nilai-nilai agama Islam dapat dilihat dari dua segi yaitu: segi nilai normatif dan segi nilai operatif. Segi nilai normatif adalah standar atau patokan norma yang mempengaruhi manusia dalam menentukan pilihannya di antara caracara tindakan alternatif yang menitikberatkan pada pertimbangan baik buruk, benar salah, hak batil, dan diridai tidak diridai. Pengertian nilai normatif ini mencerminkan pandangan dari sosiolog yang memiliki penekanan utamanya pada norma sebagai faktor eksternal yang mempengaruhi tingkah laku manusia. Secara garis besar, penggunaan kriteria benar salah dalam menetapkan nilai 
adalah dalam hal ilmu (sains). Sedangkan kriteria baik buruk digunakan dalam menetapkan nilai dalam hal etika. Nilai operatif adalah suatu tindakan yang mengandung lima kategori yang menjadi prinsip standarisasi tingkah laku manusia yaitu baik, setengah baik, netral, kurang baik dan buruk (Mulyana, 2004: 9).

Alquran tidak hanya sebagai petunjuk bagi suatu umat tertentu dan untuk periode waktu tertentu, melainkan menjadi petunjuk yang universal dan sepanjang waktu. Alquran selalu eksis dalam setiap zaman dan tempat. Petunjuknya sangat luas seperti luasnya umat manusia dan meliputi segala aspek kehidupan. Bukan saja ilmu-ilmu keislaman yang digali secara langsung dari Alquran, seperti ilmu tafsir, fikih dan tauhid, akan tetapi Alquran juga merupakan sumber ilmu pengetahuan dan teknologi, karena banyak sekali isyarat-isyarat Alquran yang membicarakan peroalan-perosalan sains dan teknologi dan bidang keilmuan lainnya.

Tuntunan dan anjuran untuk mempelajari Alquran dan menggali kandungannya serta menyebarkan ajaran-ajarannya dalam praktik kehidupan masyarakat merupakan tuntunan yang tidak akan pernah habis. Menghadapi tantangan dunia modern yang bersifat sekuler dan materialistis, umat Islam dituntut untuk menunjukkan bimbingan dan ajaran Alquran yang mampu memenuhi kekosongan nilai moral kemanusiaan dan spiritualitas, di samping membuktikan ajaran-ajaran Alquran yang bersifat rasional dan mendorong umat manusia untuk mewujudkan kemajuan dan kemakmuran serta kesejahteraan.

Hadis berperan sebagai sumber ilmu pengetahuan di antaranya ialah sebagai pengukuh terhadap ayat-ayat Alquran, sebagai penjelasan terhadap maksud ayat-ayat Alquran, dan menetapkan hukum yang tidak disebutkan dalam Alquran (Al-Malik, 2009: 3). Hadis juga merupakan sumber ilmu pengetahuan keagamaan, kemanusiaan, dan sosial yang dibutuhkan umat manusia untuk meluruskan jalan mereka, membetulkan kesalahan mereka, ataupun melengkapi pengetahuan eksperimental mereka.

Hadis dapat menentukan hukum dan rujukan pola kehidupan, karena Hadis dalam posisinya sebagai sumber kedua sekaligus bentuk tafsir dan penjelasan terhadap Alquran. Terlebih dalam tataran praktik, Hadis lebih mempunyai kecenderungan aplikatif. Unsur dalam Hadis selain merupakan bagian dari wahyu juga bentuk responsibilitas terhadap persoalan yang muncul, karena Hadis merupakan interpretasi dan rangkuman dari Nabi Muhammad saw. Dalam konsep pendidikan Islam, Hadis merupakan landasan filosofis dalam pengembangan sistematika pendidikan Islam, terlebih dalam Hadis banyak 
sekali menekankan tentang akhlak dan pendidikan (Jamila, 2016: 78). Hadis juga merupakan sumber ilmu pengetahuan, keagamaan, kemanusiaan, dan sosial yang dibutuhkan umat manusia untuk meluruskan jalan mereka, membetulkan kesalahan mereka, ataupun melengkapi pengetahuan eksperimental mereka. Hadis juga mengandung informasi-informasi tentang berbagai peristiwa yang berkaitan dengaan masa depan sehingga dapat dijadikan rujukan sumber ilmu pengetahuan, termasuk pengetahuan biologi (Rahman, 2011: 76).

Dari paparan di atas, bisa ditarik benang merah bahwa Alquran dan Hadis merupakan sumber hukum Islam yang mengatur semua aspek kehidupan. Kehidupan manusia dengan alam semesta, kehidupan manusia dengan TuhanNya, atau kehidupan manusia dengan manusia lainnya tercantum dalam Al qur'an dan diperjelas dalam Hadis. Mempelajari Alquran dan Hadis dapat mengarahkan manusia untuk mengenal kebesaran Tuhan sebagai pencipta. Dengan demikian akan menjadikan manusia yang mempelajari Al qur'an dan Hadis semakin beriman dan bertakwa kepada Tuhan serta memiliki akhlak mulia (terealisasinya nilai-nilai Islam).

\section{Integrasi Alquran dan Hadis dalam Pembelajaran Biologi untuk Pengembangan Nilai Islami Peserta Didik}

Integrasi dapat diartikan sebagai proses komplementasi yaitu memadukan antara ilmu umum (dalam hal ini biologi) dan ilmu agama (Alquran dan Hadis) yang keduanya saling mengisi dan menguatkan tetapi tetap mempertahankan eksistensi masing-masing karena sesungguhnya ilmu pengetahuan terintegrasi dan tidak terpisah-pisah. Integrasi juga dapat diartikan memadukan ilmu umum (dalam hal ini biologi) dengan Alquran dan Hadis karena ilmu merupakan satu kesatuan yang sumbernya dari Allah Swt. (Abunittaka, 2005: 147). Integrasi adalah suatu kesatuan yang utuh, tidak terpecah belah dan bercerai berai. Integrasi meliputi kebutuhan atau kelengkapan anggota-anggota yang membentuk suatu kesatuan dengan jalinan hubungan yang erat, harmonis dan mesra antara anggota kesatuan itu. Sedangkan yang dimaksud dengan integrasi Alquran dan Hadis dalam pembelajaran biologi adalah proses memadukan Alquran dan Hadis terhadap sebuah konsep dalam mata pelajaran biologi sehingga menjadi suatu kesatuan yang koheren dan tidak bisa dipisahkan atau proses pembauran hingga menjadi satu kesatuan yang utuh dan bulat.

Integrasi Alquran dan Hadis dalam pembelajaran biologi bertujuan untuk mengembangkan nilai Islami peserta didik sekaligus mengembangkan 
aspek pengetahuan biologi. Tujuan dari integrasi ini adalah memberikan pemahaman yang komprehensif kepada peserta didik terhadap suatu pembahasan, yang pada akhirnya dapat memunculkan nilai-nilai yang baik dan akhlak mulia bagi peserta didik di dalam menjalani kehidupannya, dan menambah keimanan dan keyakinannya terhadap kekuasaan Allah Swt. Itegrasi nilai-nilai Islam dalam pembelajaran biologi akan memberikan kekuatan pada ranah afektif, psikomotor dan kognitif. Ketika hal ini diimplementasikan dalam pembelajaran biologi di sekolah, akan memberikan hasil belajar yang holistik dalam semua ranah belajar peserta didik. Hal ini akan memberikan warna yang berbeda dari yang selama ini banyak terjadi dimana ranah kognitif begitu dominan atau bahkan menjadi satu-satunya yang dikembangkan dalam pembelajaran di sekolah.

Pentingnya integrasi nilai-nilai Islam yang bersumber dari Alquran dan Hadis dalam pembelajaran sains (biologi) menjadi satu kerangka normatif dalam merumuskan tujuan pendidikan sebagaimana diungkapkan Ali dan Luluk dalam Muspiroh (2014) bahwa tujuan penanaman nilai-nilai Islam adalah: a) mengembangkan wawasan spiritual yang semakin mendalam dan mengembangkan pemahaman rasional mengenai Islam dalam konteks kehidupan terutama yang berkaitan dengan ayat-ayat kauniyah (alam). b) Membekali siswa dengan berbagai kemampuan pengetahuan alam. c) Mengembangkan kemampuan pada diri siswa untuk menghargai dan membenarkan superioritas komparatif khazanah pengetahuan Islam di atas semua khazanah pengetahuan yang lain. d) Memperbaiki dorongan emosi melalui pengalaman imajinatif, sehingga kemampuan kreatif dapat berkembang dan berfungsi mengetahui norma-norma Islam yang benar dan yang salah. e) Membantu anak yang sedang tumbuh untuk belajar berpikir secara logis dan membimbing proses pemikirannya dengan berpijak pada hipotesis dan konsepkonsep pengetahuan alam yang dituntut.

Ada beberapa manfaat dan hikmah yang dapat diperoleh jika pembelajaran pokok bahasan biologi diintegrasikan dengan kajian ayat Alquran dan Hadist. Hasil penelitian Jelen \& Lockett (2014) menunjukan bahwa variabel religius meliputi pandangan keagamaan dan kitab suci berhubungan erat dan signifikan terhadap perubahan sikap peserta didik menjadi lebih baik. Integrasi nilai agama ke dalam kurikulum pembelajaran berkontribusi menghasilkan manusia yang baik dalam mengaplikasikan pengetahuan dan keterampilan sesuai dengan Islam (Jamilah dkk , 2014; Mufid, 2014). Melalui pengenalan dan pemahaman akan ayat-ayat Alquran dan Hadist yang berkaitan dengan biologi 
diharapkan akan memberikan manfaat/ fungsi antara lain:

a. Mendapatkan petunjuk fakta ilmiah yang belum dapat dicapai oleh sains modern

Meningkatkan keimanan dengan dibuktikannya kebenaran wahyu yang datang sebelum sains moderen mengungkapkan fakta tentang tema wahyu tertentu

b. Mengenal Allah melalui ke-Maha Kuasa-an penciptaan-Nya

Tanpa mengaitkan pembelajaran Biologi dengan kajian Alquran dan Hadis, peserta didik hanya akan mempelajari fakta ilmiah. Alquran dalam memaparkan fenomena alam mencantumkan Allah sebagai subyek pencipta dan mencantumkan unsur perenungan (misal: Apakah kamu tidak memikirkannya?) agar pembacanya bisa lebih mendalami sifat Allah sebagai pencipta fenomena alam tersebut.

c. Menelaah apakah perkembangan teknologi sesuai dengan prinsip-prinsip Islam

Tanpa mengaitkan pembelajaran Biologi dengan kajian Alquran dan Hadis, peserta didik tidak difasilitasi untuk menjaring informasi perkembangan teknologi apakah sesuai dengan prinsip-prinsip Islam atau tidak. Peserta didik dapat saja terjebak mendukung perkembangan teknologi tersebut meskipun bertentangan dengan prinsip-prinsip Islam. Pendidikan yang mengabaikan prinsip-prinsip agama melanggar hak peserta didik untuk beribadat menurut agamanya.

d. Mengkaji fenomena alam secara komprehensif

Fenomena alam yang dijelaskan dalam Alquran tidak hanya bersifat fisikekologik, tetapi juga dijelaskan dengan segi-segi kejiwaan, etika, hukum, dan kehidupan masyarakat. Misalnya, Alquran tidak hanya menjelaskan pertumbuhan manusia dari pertemuan sperma dan ovum sampai melahirkan, lalu menjadi dewasa, tua, dan mati kemudian dihidupkan kembali, tetapi secara luas juga dijelaskan mengenai kaitan biologi dengan masalah-masalah perkawinan, perceraian, dan hubungan sosial kemasyarakatan (Naim, 2001).

Melihat tujuan adanya integrasi Alquran dan Hadis pada pembelajaran biologi yang sangat penting, maka penting sekali dikembangkan sebuah model pendidikan integratif yang memadukan antara pokok bahasan atau materi biologi dengan Alquran dan Hadis. Perpaduan yang dimaksud bukan sekedar proses percampuran biasa (Islamisasi), tetapi sebagai proses pelarutan. Integrasi 
Alquran dan Hadis dalam pembelajaran biologi merupakan suatu alternatif model pendidikan yang dirasa penting untuk mencapai tujuan pendidikan nasional yang dapat meningkatkan nilai spiritual dan intelektual peserta didik sebagaimana yang diamanatkan oleh UU Nomor 20 tahun 2003 tentang Sistem pendidikan Nasional.

Menurut Harahap (2018), pengembangan model Integrasi Alquran dan kurikulum pembelajaran sains (biologi) dapat dilakukan secara bertahap melalui tiga hal:

a. Menganalisis seluruh ayat- ayat kawniyyat yang ada dalam Alquran dan yang relevan dengan pokok bahasan atau materi.

b. Menganalisis materi atau pokok bahasan kurikulum sains (biologi) yang berkaitan dengan ayat-ayat kawniyyat

c. Mengintegrasikannya ayat-ayat kawniyyat dalam Alquran terhadap materi atau pokok bahasan pada kurikulum sains kemudian dikumpulkan dalam satu buku pembahasan yang dinamakan kurikulum sains berbasis Alquran.

Menurut Minarno (2017), Integrasi Alquran atau Hadis dalam pembelajaran biologi dapat dilakukan dengan dua macam model yakni: 1) Model integrasi Alquran sebagai sumber inspirasi, yakni meletakkan Alquran pada awal pembelajaran sebagai payung pengetahuan atau sumber inspirasi ilmu pengetahuan atau sumber rujukan utama yang selanjutnya dijelaskan oleh berbagai fenomena dalam sains. 2) Model integrasi Alquran sebagai sumber konfirmasi, yakni melakukan analisis kritis/pembahasan fenomena dalam sains, yang kemudian dikonfirmasikan dengan Alquran, dalam arti temuan dalam sains adalah memperjelas apa yang telah dikermukakan Alquran. Kedua model tersebut dapat digunakan secara simultan dan bersinergi dalam pembelajaran Biologi.

Menurut Marvavilha (2018), Integrasi nilai-nilai Islam yang bersumber dari Alquran atau Hadis dalam kegiatan pembelajaran sains, khusunya biologi dapat dilakukan secara bayani, burhani, dan 'irfani. Integrasi dalam konteks bayani berupaya untuk memperjelas, mengungkap, dan menuangkan maksud pembicaraan dengan berdasarkan lafadz. Ciri utamanya adalah menggunakan teks sebagai rujukan pokok sumber pengetahuan. Dalam hal ini, teks yang dimaksud adalah ayat-ayat Alquran. Terdapat banyak ayat yang menjelaskan mengenai sains, dan dalam hal ini sains dan agama bertujuan untuk dapat menghantarkan manusia menjadi semakin mengagungkan Allah Swt. Adapun burhani, yaitu argumentasi yang kuat dan jelas. Pola burhani berangkat dari 
nalar, dan nalar bermula dari proses abstraksi yang bersifat 'aqly terhadap suatu realitas sehingga muncul makna, dan makna butuh aktualisasi agar bisa dipahami. Burhani bersumber pada realitas alam, sosial, dan budaya. Integrasi sains dalam konteks burhani, yakni mengintegrasikan materi sains dengan realitas yang ada di alam, lingkungan sosial, dan lingkungan budaya yang ada di daerah masing-masing. Integrasi dalam konteks irfani yakni mengaitkan suatu ilmu dengan manfaat dari ilmu tersebut. Dalam konteks sains, materi sains diintegrasikan dengan manfaat yang ada dalam kehidupan sehari-hari.

Menurut Batubara (2018), metode integrasi sains (biologi) dan Islam (melalui Alquran dan Hadis), dapat dilakukan dengan cara: 1) menjadikan Alquran dan Hadis sebagai sumber ilmu pengetahuan, 2) memperluas materi kajian agama Islam dan menghindari dikotomi ilmu, 3) menumbuhkan pribadi yang berkarakter ulul albab, 4) menelusuri ayat-ayat Alquran yang berbicara tentang sains, 5) mengembangkan kurikulum pendidikan.

Berdasarkan alternatif model atau metode pengintegrasian Alquran atau Hadis yang dipaparkan di atas, penulis merangkum dan memberikan alternatif model atau metode integrasi Alquran dan Hadis dalam pembelajaran biologi:

a. Pendataan dan analisis ayat Alquran dan Hadis yang berkaitan dengan pokok bahasan atau materi biologi baik secara tersirat maupun tersurat. Secara tersurat maksudnya adalah merujuk ayat-ayat yang benar-benar teksnya sesuai dengan pokok bahasan biologi tertentu, sedangkan secara tersirat dapat dilakukan dengan memperdalam tafsir terhadap ayat tertentu yang teksnya tidak tertulis secara gamblang.

b. Mengimplementasikan pengintegrasian ayat Alquran dan Hadis yang sudah ditemukan tersebut dalam proses pembelajaran biologi. Hal ini dapat dilakukan dengan merancang proses pembelajaran yang dapat mengintegrasikan ayat Alquran dan Hadis yang sudah ditemukan tersebut dengan pokok bahasan atau materi biologi yang dipelajari. Pemilihan model pembelajaran sangat menentukan dalam hal ini.

c. Melakukan evaluasi terhadap proses integrasi yang sudah dilakukan dalam proses pembelajaran. Dalam hal ini diperlukan alat evaluasi yang juga mengarah pada pengetahuan tentang nilai yang diperoleh peserta didik setelah mengikuti pembelajaran biologi dengan model integrasi.

Dalam tulisan ini, penulis akan memberikan contoh ayat Alquran dan Hadis yang dapat diintegrasikan dalam pembelajaran biologi, salah satunya adalah pada materi atau pokok bahasan perubahan lingkungan yang dipelajari 
di kelas X SMA. Kaitannya dengan perubahan lingkungan, dapat dikaji ayat Alquran Surat Ar-Ruum ayat 41 dan Surat Ali 'Imran ayat 182:

Telah nampak kerusakan di darat dan di laut disebabkan karena perbuatan tangan manusia, supaya Allah merasakan kepada mereka sebagian dari (akibat) perbuatan mereka, agar mereka kembali ke jalan yang benar (Q.S. Ar-Ruum: 41).

(Azab) yang demikian itu adalah disebabkan perbuatan tanganmu sendiri, dan bahwasanya Allah sekali-kali tidak menganiaya hamba- Nya (Q.S. Ali 'Imran: 182).

Adapun ayat Hadist yang dapat dipakai untuk integrasi antara lain:

Rasulullah saw. bersabda: "Tidaklah seorang muslim menanam tanaman, kemudian tanaman itu dimakan oleh burung, manusia, ataupun hewan, kecuali baginya dengan tanaman itu adalah sedekah." (H.R. Al-Bukhari dan Muslim dari Anas).

Setelah diperoleh ayat Alquran dan Hadis yang sesuai dengan pokok bahasan biologi, selanjutnya ayat tersebut dapat diintegrasikan ke dalam pembelajaran biologi dengan model pembelajaran tertentu. Sebagai contoh misalnya dengan model pembelajaran Problem Based Learning (PBL) disertai kajian ayat Alquran dan Hadis. Dalam proses ini dapat disajikan permasalahanpermasalahan lingkungan yang terjadi di bumi, kemudian peserta didik diminta untuk menganalisis permasalahan tersebut dan mencari solusi atas permasalahan yang ada dengan merujuk pada ayat Alquran dan Hadis yang disajikan. Setelah pembelajaran selesai harus dilakukan evaluasi terhadap capaian pengetahuan maupun nilai Islami yang diperoleh peserta didik melalui proses pembelajaran yang telah berlangsung.

Biologi menurut Islam seharusnya mengandung keajaiban alam yang luar biasa, beserta hukum-hukumnya yang teratur, rapi, dan harmonis. Jadi, selain berperan penting dalam menghasilkan berbagai teknologi dan produknya, sains biologi juga berperan sebagai media pengenalan dan objek tafakkur manusia kepada Tuhan. Perintah untuk mentafakkuri dan merenungkan ciptaan Tuhan di langit dan di bumi banyak ditemukan dan diperintahkan dalam Alqur 'an dan Hadis (Rahman, 2011). Dengan demikian, integrasi Alquran dan Hadis dalam pembelajaran biologi perlu dilakukan untuk menumbuhkan nilai-nilai religus (Islami) pada diri peserta didik guna tercapainya tujuan pendidikan nasional. 


\section{Kesimpulan}

Alquran dan Hadis dapat dijadikan sebagai sumber pembentukan nilai Islam peserta didik dalam pembelajaran biologi. Integrasi Alquran dan Hadis dalam proses pembelajaran biologi, peserta didik dapat memperoleh pengetahuan tentang konsep biologi sekaligus dapat mengembangkan nilai-nilai Islami agar peserta didik semakin menjadi manusia yang beriman dan bertakwa serta berakhlak mulia seperti yang diharapkan dalam tujuan pendidikan nasional. Integrasi Alquran dan Hadis dalam pembelajaran biologi dapat dilakukan dengan: 1) Mendata dan menganalisis ayat Alquran dan Hadis yang sesuai dengan pokok bahasan atau materi biologi baik secara tersirat maupun terSurat, 2) Mengimplementasikan pengintegrasian ayat Alquran dan Hadis yang sudah ditemukan dalam proses pembelajaran biologi dengan pemilihan model pembelajaran tertentu yang sesuai; 3) Melakukan evaluasi terhadap proses integrasi yang sudah dilakukan dalam proses pembelajaran biologi.

\section{Daftar Pustaka}

Abdurrahman, M. (2011). Metode kritik Hadis. Bandung: Remaja Rosdakarya. Abunittaka. (2005). Integrasi ilmu agama dan ilmu umum. Jakarta: PT Raja Grapindo Persada.

Adisusilo, S. (2013). Pembelajaran Nilai Karakter Konstruksi dan VCT Sebagai Inovasi Pendekatan Pembelajaran Afektif. Jakarta: PT Rajagrafindo Persada.

Al-Malik \& Alawi, M. (2009). Ilmu ushul Hadis. Yogyakarta: Pustaka Pelajar.

Arifin, H.M. (2010). Filsafat pendidikan Islam (Edisi Revisi). Jakarta: Bumi Aksara.

Badan Pengembangan dan Pembinaan Bahasa. (2016). KBBI daring. Jakarta: Kementerian Pendidikan dan Kebudayaan Republik Indonesia.

BNSP. (2006). Standar isi untuk satuan pendidikan dasar dan menengah: standar kompetensi dan kompetensi dasar SMA/MA.

Batubara, H. H. (2016). Metode dan model integrasi sains dan Islam di Perguruan Tinggi Agama Islam. Diperoleh dari https://www.researchgate. net/publication/324744404.

Harahap, A. (2018). Integrasi Alquran dan materi pembelajaran kurikulum sains pada tingkat sekolah di Indonesia: Langkah menuju kurikulum 
sains berbasis Alquran. Jurnal Penelitian Medan Agama. 9(1). 21-46.

Iryani, E. (2017). Alquran dan ilmu pengetahuan. Jurnal Ilmiah Universitas Batanghari Jambi. 17(3). 66-83.

Jamila. (2016). Pendidikan berbasis Islam yang memandirikan dan mendewasakan. Jurnal EduTech, 2(2), 73-83.

Jamilah, J., Najib, A. A., Dzulkhairi, M., Ariff, H., \& Ismail, N. N. (2014). Integration of Islamic input in medical curriculum-Universiti Sains Islam Malaysia (USIM). The International Medical Journal of Malaysia, 13(2), 73-77.

Jelen, T. G., \& Lockett, L. A. (2014). Religion, Partisanship, and Attitudes Toward Science Policy. SAGE Open, 4(1). Diperoleh dari http://doi. org/10.1177/2158244013518932.

Kementerian Agama Republik Indonesia. (2010). Alquran dan tafsirnya edisi yang disempurnakan. Jakarta: Kementerian Agama Republik Indonesia.

Marvavilha, A., Suparlan, S. (2018). Model integrasi nilai Islam dalam pembelajaran sains. Humanika, Kajian Ilmiah Mata Kuliah Umum, 18 (1). 59-80. https://doi.org/10.21831/hum.v18i1.23129.

Minarno, Eko Budi. (2017). Integrasi sains-Islam dan implementasinya dalam pembelajaran biologi. Seminar Nasional Teknologi Informasi, Komunikasi dan Industri (SNTIKI) 9 Fakultas Sains dan Teknologi, UIN Sultan Syarif Kasim Riau.

Mulyana, R. (2004). Mengartikulasikan pendidikan nilai. Bandung: VC Alfabeta.

Muspiroh, N. (2014). Integrasi nilai-nilai Islam dalam pembelajaran IPA di sekolah. Artikel tidak diterbitkan.

Naim, M. (2001). Kompendium himpunan ayat-ayat Alquran yang berkaitan dengan biologi dan kedokteran. Jakarta: Hâsanah.

Nurasni, N., Darmawati, D., \& Yustini, Y. (2015). Students' Perception of Class X2 MA Darul Hikmah Pekanbaru Toward Iqro Learning Model Implementation in Biology Subject Academic Year 2014/2015. Biology Education Studies Program, The Faculty of Education and Teacher Training, University of Riau, 1-15.

Ogunbado, A. F., \& Al-Otaibi, A. M. (2013). Is quality management an Islamic value? IOSR Journal of Business and Management, 8(3), 6-13.

Permendikbud Nomor 22 Tahun 2016 tentang Standar Proses Pendidikan.

Rahman, M.T. (2011). Integrating Lessons from the Qur'an and Hadith in 
Humanika, Kajian IImiah Mata Kuliah Umum, Vol. 20. No. 2. (2020), 129-146

teaching molecular biology. Revelation and Science Journal, 01(03), 75-84.

Shalih, S. (2009). Membahas ilmu-ilmu Hadis (Terjemahan). Jakarta: Pustaka Firdaus.

Suryaningsih, Y. (2018). Penerapan Pembelajaran Biologi Berbasis Alquran Sebagai Metode untuk Pembentukan Karakter Siswa. Jurnal Bio Educatio, Volume 3, Nomor 1, April 2018, hlm. 22-33, ISSN: 2541-2280.

Susilowati, S. (2017). Pengembangan bahan ajar IPA terintegrasi nilai Islam untuk meningkatkan hasil belajar IPA. Jurnal Inovasi Pendidikan IPA, 3 (1), 78-88.

Undang-Undang Nomor 20 Tahun 2003 tentang Sistem Pendidikan Nasional. 